\title{
GLAVNE RAZLIKE V ŽIVLJENJSKI RAVNI MED SLOVENSKIMI MESTNIMI, OBMESTNIMI IN PODEŽELSKIMI OBMOČJI
}

\begin{abstract}
Marko Krevs*
Izvleček

V povprečju ima najvišjo življenjsko raven mestno, najnižjo pa podeželsko prebivalstvo. Mestna, obmestna in podeželska območja se najbolj razlikujejo glede na oskrbne, storitvene in izobraževalne razmere. Na podlagi življenjske ravni prebivalstva nekega območja le z omejeno zanesljivostjo ocenimo, ali gre za mesto, obmestje ali podeželje. Razlike vživljenjski ravni v obliki modela povežemo z dejavniki selitev prebivalcev.

Ključne besede: Življenjska raven, mesto, obmestje, podeželje, razlike med območji, dejavniki migracij, Slovenija
\end{abstract}

\section{THE MAIN DIFFERENCES IN LEVEL OF LIVING BETWEEN THE SLOVENIAN URBAN, SUBURBAN AND RURAL AREAS}

\begin{abstract}
In average, the urban population has the highest level of living, and the rural population the lowest. Urban, suburban and rural areas are best distinguished on the basis of conditions for supply, services and education. The prediction of a certain area being urban, suburban or rural, is only partialy successful. The differences in level of living are related to the factors of migrations in the form of a model.
\end{abstract}

Key words: Level of living, town, suburban areas, rural areas, differences between areas, factors of migrations, Slovenia

\footnotetext{
* Dr., Oddelek za geografijo, Filozofska fakulteta, Univerza v Ljubljani, Aškerčeva 2, SI 1000 Ljubljana
} 
Življenjska raven nam na kompleksen in bolj ali manj agregiran način predstavi življenjske okoliščine (razmere, pogoje) prebivalstva na določenem območju v določenem časovnem obdobju. Če v njeno opredelitev poleg ekonomskih vključimo tudi socialne in prostorske vsebine (vključno z okoljskimi), dobimo izredno uporabno podlago za primerjavo življenjskih razmer med območji. V prispevku na ta način predstavimo glavne razlike med mestnimi, obmestnimi in podeželskimi območji $\mathrm{v}$ Sloveniji.

Mesto, obmestje in podeželje so na splošno pojmi s prepoznavno vsebino. Težave in različni pogledi nastopijo, ko jih želimo podrobneje opredeliti, jih med seboj ločiti ali prikazati njihovo prostorsko razprostranjenost. Podobne težave poznamo tudi pri opredeljevanju in merjenju življenjske ravni. Zato se v prispevku omejujemo na zelo splošno raven. Pojme mesto, obmestje in podeželje nadomestimo s pojmi mestna, obmestna in podeželska območja, s čimer želimo poudariti, da se zavedamo ohlapnosti uporabljenih opredelitev teh območij. Za prikaz življenjske ravni uporabimo trinajst "vsebin življenjske ravni", ki na razmeroma splošen (agregiran) način predstavljajo življenjske razmere prebivalstva; izračunane so namreč na podlagi 108 kazalcev (Krevs,1999). Naš cilj torej niso točni izračuni in razkrivanje drobnih razlik med območji z vidika življenjske ravni, temveč razkrivanje glavnih, najpomembnejših razlik.

Tovrstna spoznanja so lahko podlaga ne le za razmišljanja o razlikah v življenjskih razmerah na različnih območjih, temveč na primer tudi o različnih prilagoditvah prebivalcev teh območij na obstoječe življenjske razmere, različnih načinih življenja ali razlikah $\mathrm{v}$ kakovosti njihovega življenja. Z geografskega vidika so posebno zanimive možnosti za razmišljanje o procesih $\mathrm{v}$ prostoru, ki nastajajo zaradi razlik $\mathrm{v}$ življenjski ravni. Eden temeljnih družbeno-geografskih procesov, ki jih sprožajo ali vsaj nanje vplivajo tovrstne razlike med območji, so selitve prebivalstva. Na slednje pa se na primer tesno navezujejo procesi urbanizacije, suburbanizacije in deurbanizacije. S preprostim modelom možnih objektivnih dejavnikov selitev prebivalstva med mestnimi, obmestnimi in podeželskimi območji v Sloveniji želimo $v$ zaključnem delu prispevka vzpodbuditi prav ta "procesni" pogled na razlike $\mathrm{v}$ življenjski ravni med obravnavanimi območji.

\section{METODOLOGIJA}

Temeljna prostorska enota, ki jo uporabimo v raziskavi, je krajevna skupnost. Mestna območja ("krajevne skupnosti z mestnim značajem") določimo na podlagi Vrišerjeve opredelitve mest in mestnih občin (Vrišer, 1995, 105; varianta C): "mestne krajevne skupnosti" so tiste, ki so v mestni občini in so del strnjenega naselja, v navedenem viru imenovanega med mesti. "Obmestne krajevne skupnosti" opredelimo na podlagi 
njihove lege v neposredni bližini "mestnih krajevnih skupnosti". Vse ostale krajevne skupnosti opredelimo kot podeželske (slika 1).

Slika 1: Slovenske krajevne skupnosti z mestnim, obmestnim in podeželskim značajem. "Mestne krajevne skupnosti" so prikazane z rdečo barvo.

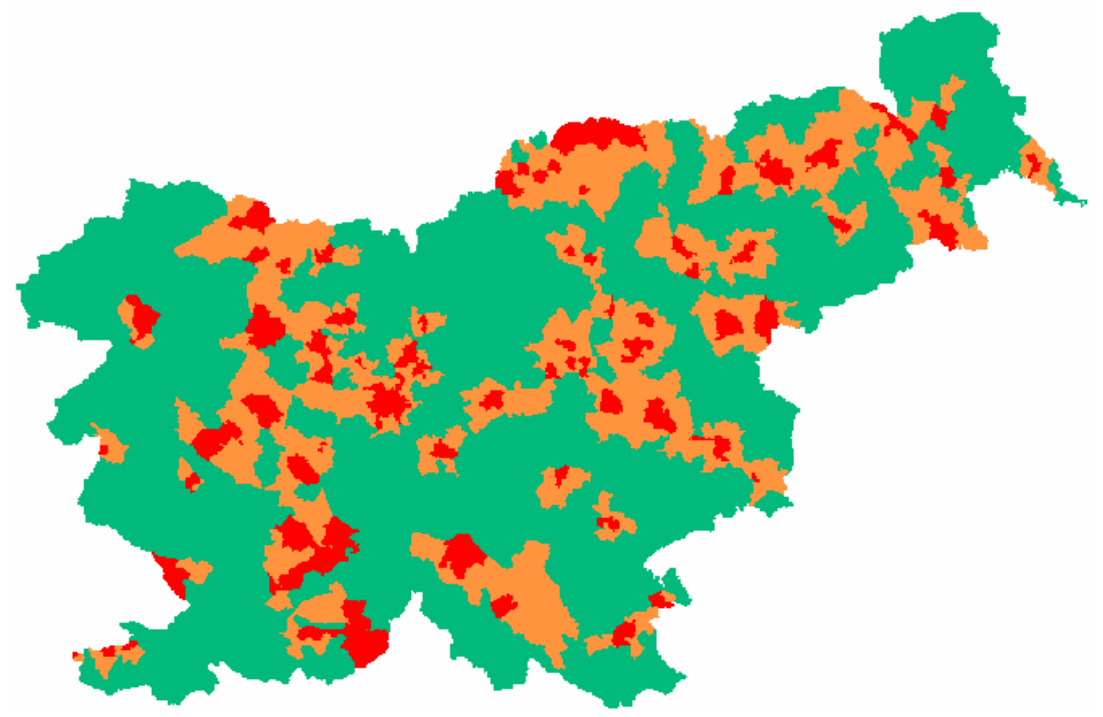

Kazalce življenjske ravni, ki se nanašajo na prvo polovico 1990. let, združimo v trinajst "delnih indeksov življenjske ravni" (predstavljajo "vsebine življenjske ravni"; Krevs, 1998; v oklepajih so navedene oznake delnih indeksov, ki jih ponekod uporabimo $\mathrm{v}$ nadaljnjem besedilu): premoženje in dohodki prebivalstva (I1), premoženje kmečkih gospodarstev (I2), stanovanjske razmere (I3), značilnosti prebivalstva (I4), zaposlitvene razmere (I5), izobraževalne razmere (I6), oskrbne razmere (I7), storitvene razmere (I8), možnosti za opravljanje prostočasnih dejavnosti (I9), prometne razmere (I10), naravna ogroženost na območju bivanja (I11), naravne razmere na območju bivanja (I12) in onesnaženost bivalnega okolja (I13). Izbor kazalcev in način agregiranja je podrobno pojasnjen v navedeni raziskavi.

Za prikaz in analizo razlik med mestnimi, obmestnimi in podeželskimi območji uporabimo "profile" življenjske ravni, primerjavo "skupnih indeksov življenjske ravni", analizo variance in diskriminančno analizo. S prvo metodo za mestna, obmestna in podeželska območja ločeno prikažemo povprečne vrednosti posameznih "delnih indeksov življenjske ravni". "Skupni indeksi življenjske ravni" so standardizirani seštevki trinajstih "delnih indeksov življenjske ravni". Pokažejo nam, kje so bolj "nakopičene" ugodne, in kje bolj neugodne življenjske razmere. $Z$ analizo 
variance ugotavljamo statistično pomembnost razlik med mestnimi, obmestnimi in podeželskimi območji z vidika posameznih vsebin življenjske ravni. S pomočjo diskriminančne analize pa na podlagi splošnih (povprečnih) značilnosti mestnih, obmestnih in podeželskih območij vsako krajevno skupnost poskušamo uvrstiti v tisto izmed treh kategorij, ki ji je najbolj podobna. Na ta način posredno opozorimo na (ne)zanesljivost izhodiščne opredelitve "mestnih", "obmestnih" in "podeželskih krajevnih skupnosti".

\section{ANALIZA RAZLIK MED MESTNIMI, OBMESTNIMI IN PODEŽELSKIMI OBMOČJI}

$\mathrm{Na}$ podlagi primerjave vseh treh "profilov življenjske ravni" (slika 2) lahko ugotovimo glavne razlike $\mathrm{v}$ življenjski ravni med obravnavanimi območji. Mesta na splošno močno izstopajo z ugodnejšimi storitvenimi, izobraževalnimi, oskrbnimi, prometnimi razmerami, možnostmi za opravljanje prostočasnih dejavnosti, zaposlitvenimi in stanovanjskimi razmerami. $\mathrm{V}$ primerjavi $\mathrm{s}$ podeželskimi in obmestnimi območji pa so razmere izrazito bolj neugodne $\mathrm{z}$ vidika premoženja kmečkih gospodarstev in onesnaženosti bivalnega okolja. Na podeželju so z večine vidikov življenjske ravni razmere bolj neugodne, kot na mestnih in obmestnih območjih. Izjema so $\mathrm{v}$ povprečju najugodnejše razmere $\mathrm{z}$ vidika (ne)onesnaženosti bivalnega okolja, premoženja kmečkih gospodarstev in značilnosti prebivalstva. Slednje je glede na ustaljene predstave o posledicah večdesetletnih neugodnih prebivalstvenih in gospodarskih procesov na podeželju nekoliko presenetljivo. Tak rezultat pojasnimo na podlagi "sestave" indeksa prebivalstvenih razmer. Poleg temeljnih demografskih in izobrazbenih značilnosti prebivalstva namreč $\mathrm{V}$ izračunavanje indeksa vključimo tudi kazalce o avtohtonosti, etnični in kulturni heterogenosti prebivalstva ter gostoti poselitve, ki na podeželju kažejo na splošno ugodnejše razmere, kot na mestnih in obmestnih območjih.

Primerjava vrednosti skupnega indeksa življenjske ravni za mestna, obmestna in podeželska območja (slika 2) nam na zgoščen način pove, da so na splošno, glede na skupni seštevek vseh delnih indeksov, najugodnejše življenjske razmere v mestih, najbolj neugodne pa na podeželju. 
Slika 2: Primerjava "profilov" in skupnega indeksa življenjske ravni med mestnimi, obmestnimi in podeželskimi območji.
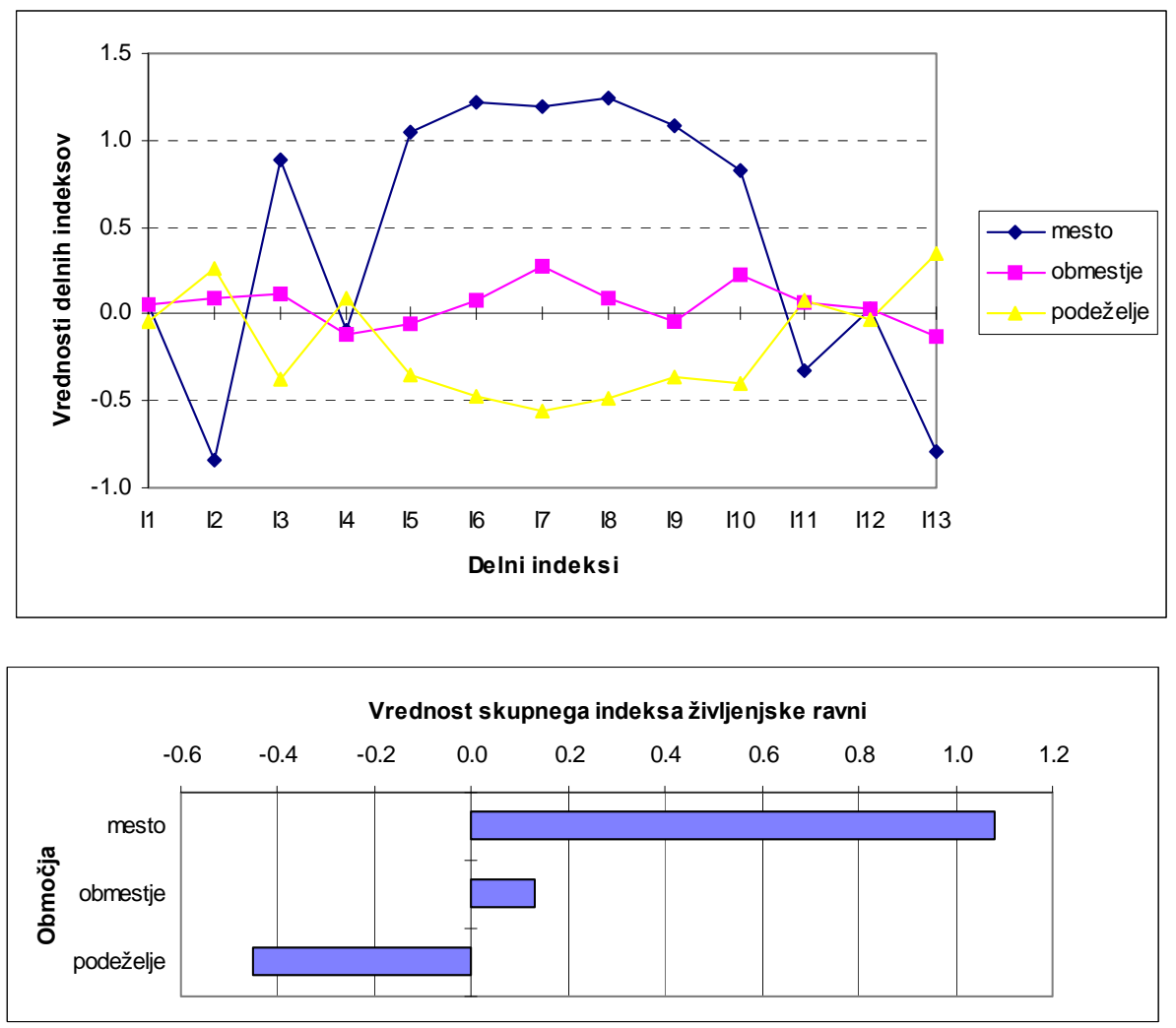

Nadaljnje analize nam statistično potrjujejo, kar smo med drugim spoznali že v dosedanjem, opisnem delu analize. Rezultati analize variance (preglednica 1) kažejo, da so na splošno največje razlike med slovenskimi mestnimi, obmestnimi in podeželskimi območji z vidika oskrbnih, storitvenih in izobraževalnih razmer. Na drugi strani se ta območja na splošno najmanj razlikujejo $\mathrm{z}$ vidika naravnih razmer na območju bivanja, premoženja in dohodkov prebivalstva, značilnosti prebivalstva in naravne ogroženosti na območju bivanja. Slednje nikakor ne pomeni, da se območja s teh vidikov ne razlikujejo, temveč da se te vsebine življenjske ravni v prostoru spreminjajo ne glede na "mestnost", "obmestnost" ali "podeželskost" območij. Zato jih lahko opredelimo kot lokalne modifikatorje življenjske ravni na mestnih, obmestnih in podeželskih območjih.

Rezultati diskriminančne analize kažejo, da prva (glavna) diskriminančna funkcija pojasni več kot 95 odstotkov variance v življenjski ravni med mestnimi, obmestnimi 
in podeželskimi območji. $\mathrm{S}$ to diskriminančno funkcijo so korelacijsko močno povezani (preglednica 2) tisti delni indeksi življenjske ravni, za katere smo že ugotovili, da vsak posebej dobro kaže razlike med obravnavanimi območji.

Preglednica 1: Preizkusi enakosti povprečij posameznih delnih indeksov življenjske ravni za mestna, obmestna in podeželska območja v Sloveniji (analiza variance).

\begin{tabular}{|l|r|}
\cline { 2 - 2 } \multicolumn{1}{c|}{} & F \\
\hline I1 premoženje in dohodki prebivalstva & 1.85 \\
\hline I2 premoženje kmečkih gospodarstev & 126.51 \\
\hline I3 stanovanjske razmere & 182.82 \\
\hline I4 značilnosti prebivalstva & 5.64 \\
\hline I5 zaposlitvene razmere & 228.66 \\
\hline I6 izobraževalne razmere & 416.19 \\
\hline I7 oskrbne razmere & 526.52 \\
\hline I8 storitvene razmere & 448.53 \\
\hline I9 možnosti za opravljanje prostočasnih dejavnosti & 254.27 \\
\hline I10 prometne razmere & 182.16 \\
\hline I11 naravna ogroženost na območju bivanja & 15.45 \\
\hline I12 naravne razmere na območju bivanja & 0.50 \\
\hline I13 onesnaženost bivalnega okolja & 144.04 \\
\hline
\end{tabular}

Vse razlike med grupimi povprečji so statistično visoko pomembne, razen za I1 in I12.

Preglednica 2: Strukturna matrika s korelacijskimi koeficienti med delnimi indeksi življenjske ravni in diskriminančnima funkcijama.

\begin{tabular}{|l|r|r|}
\cline { 2 - 3 } \multicolumn{1}{c|}{} & \multicolumn{2}{c|}{ Funkcija } \\
\cline { 2 - 3 } \multicolumn{1}{c|}{} & 1 & 2 \\
\hline I7 oskrbne razmere & 0.69 & 0.45 \\
\hline I8 storitvene razmere & 0.64 & -0.04 \\
\hline I6 izobraževalne razmere & 0.62 & -0.05 \\
\hline I9 možnosti za opravljanje prostočasnih dejavnosti & 0.48 & -0.31 \\
\hline I5 zaposlitvene razmere & 0.45 & -0.33 \\
\hline I3 stanovanjske razmere & 0.41 & 0.07 \\
\hline I10 prometne razmere & 0.40 & 0.34 \\
\hline I13 onesnaženost bivalnega okolja & -0.36 & -0.12 \\
\hline I2 premoženje kmečkih gospodarstev & -0.33 & 0.33 \\
\hline I4 značilnosti prebivalstva & -0.06 & -0.21 \\
\hline I11 naravna ogroženost na območju bivanja & -0.11 & 0.18 \\
\hline I1 premoženje in dohodki prebivalstva & 0.03 & 0.11 \\
\hline I12 naravne razmere na območju bivanja & 0.02 & 0.05 \\
\hline
\end{tabular}


Poizkus uvrstitve vsake krajevne skupnosti v tisto kategorijo ("mesto", "obmestje", "podeželje"), ki ji je najbolj podobna glede na vrednosti delnih indeksov življenjske ravni pokaže, da na podlagi življenjske ravni na nekem območju ne moremo popolnoma zanesljivo ugotoviti, ali je območje "mestno", "obmestno" ali "podeželsko". Še najbolj zanesljivo lahko na tak način ugotovimo mestna območja ( $88 \%$ pravilno uvrščenih od vseh "mestnih" KS), nekoliko manj zanesljivo obmestna ( $71 \%$ od vseh "obmestnih" KS) in podeželska območja ( $72 \%$ od vseh "podeželskih" KS). Zanimivo si je ogledati nekatere napačne uvrstitve: $12 \%$ "mestnih" KS je bilo "spoznanih" kot "obmestje", od podeželskih je bila več kot četrtina KS "spoznana" kot "obmestje", en odstotek (8 KS) pa celo kot "mestna" krajevna skupnost.

\section{RAZLIKE V ŽIVLJENJSKI RAVNI IN MIGRACIJE}

Medobmočne razlike $\mathrm{v}$ življenjski ravni so lahko pomemben, ponavadi celo glavni dejavnik selitev prebivalstva. Po Malačiču (1996) je splošno vodilo migracij prizadevanje migrantov, da zase in za svojo družino dosežejo boljšo (materialno) življenjsko raven. Zato se selijo na območja z boljšimi (ekonomskimi) možnostmi. V širše opredeljeni življenjski ravni (na primer United Nations, 1954, Drewnowski, 1966, Knox, 1974, Krampuš-Trop, 1995 , Krevs, 1996, 1998, tudi v tem prispevku) poleg ekonomskih upoštevamo številne druge življenjske razmere, ki lahko pomembno vplivajo na odločitev o selitvi.

DeBlij $(1993,113)$ poudarja še en pomemben vidik odločanja za migriranje. Selitve so po njegovem mnenju najpogosteje posledica migrantove zaznave, da so razmere na nekem drugem območju boljše, varnejše ali udobnejše. To pomeni, da ni nujno, da so razmere tudi res boljše, temveč, da imajo migranti svoja merila za primerjavo življenjskih razmer med območji, ki se lahko razlikujejo od "pričakovanih".

Vendarle to ne pomeni, da ne moremo proučevati in upoštevati pomembnejših, pogostejših dejavnikov, ki vplivajo na selitve prebivalstva. V demogeografski literaturi sta se udomačila angleška pojma push factors in pull factors. Prvi predstavlja dejavnike, ki delujejo na prvotnem območju in po mnenju migranta negativno vplivajo na njegovo (ali družinsko) življenjsko raven. Drugi pojem pa predstavlja "dejavnike privlačnosti", ki delujejo na ciljnem območju in po mnenju migranta ugodno vplivajo na njegovo (ali družinsko) življenjsko raven.

Na podlagi rezultatov naše raziskave o objektivno izmerjenih razlikah v življenjski ravni med mestnimi, obmestnimi in podeželskimi območji (predstavljenih na sliki 2) izdelamo preprost model dejavnikov, ki lahko vplivajo na odločitve o selitvah prebivalstva v Sloveniji (slika 3). Kot možni dejavniki so navedene le vsebine življenjske ravni, ki se med določenima "tipoma" območij pomembno razlikujejo. Ali in koliko ti dejavniki dejansko vplivajo na selitve, je v veliki meri odvisno od tega, 
kako jih zaznavajo in vrednotijo migranti. Prav mogoče pa je, da se nekateri migranti preselijo povsem ne glede na te dejavnike, na primer $\mathrm{v}$ primeru selitve $\mathrm{k}$ sorodnikom ali ker mu je na ciljnem območju selitve "bolj všeč". Ob uporabi modela se moramo zavedati, da model temelji na povprečnih razlikah $\mathrm{v}$ posameznih vsebinah življenjske ravni med obravnavanimi območji, da mesto, obmestje in podeželje niso homogene kategorije (območja iste kategorije se lahko močno razlikujejo) ter da sta uporabljeni opredelitvi obmestnih in podeželskih območij precej ohlapni.

Ne glede na to, ali migranti upoštevajo navedene dejavnike, je iz modela mogoče razbrati, katere življenjske razmere se praviloma (v povprečju) močno spremenijo $\mathrm{s}$ selitvami med obravnavanimi tremi "tipi" območij v Sloveniji. S selitvami iz mest se na primer izrazito spremeni premoženje kmečkega prebivalstva (kar je seveda posledica kmetovanja izven mest) in se zmanjša onesnaženost bivalnega okolja. Slednje se znatno izboljša tudi $s$ selitvami iz obmestij na podeželje. S selitvijo iz mesta na obmestje se na primer najbolj poslabšajo zaposlitvene, izobraževalne in storitvene razmere, medtem ko se s selitvijo iz mesta na podeželje najbolj poslabšajo oskrbne, storitvene in izobraževalne razmere (navedene po padajoči zanesljivosti sprememb).

$\mathrm{Na}$ sliki so označene tudi smeri procesov urbanizacije, suburbanizacije in deurbanizacije. Prikazane razlike $\mathrm{v}$ življenjski ravni med obravnavanimi območji so nam lahko v pomoč tudi pri opisovanju in razlagi teh procesov v Sloveniji. Predvsem pri povezovanju modela s procesom suburbanizacije se moramo zavedati ohlapnosti opredelitve obmestnih območij, ki gotovo ne zajamejo vseh suburbanih območij. 
Slika 3: Model možnih objektivnih dejavnikov selitev prebivalstva v Sloveniji med mestnimi, obmestnimi in podeželskimi območji, izdelan na podlagi razlik v življenjski ravni med območji. Vsebine življenjske ravni, ki se s selitvami najbolj spremenijo, so navedene po padajoči zanesljivosti sprememb.

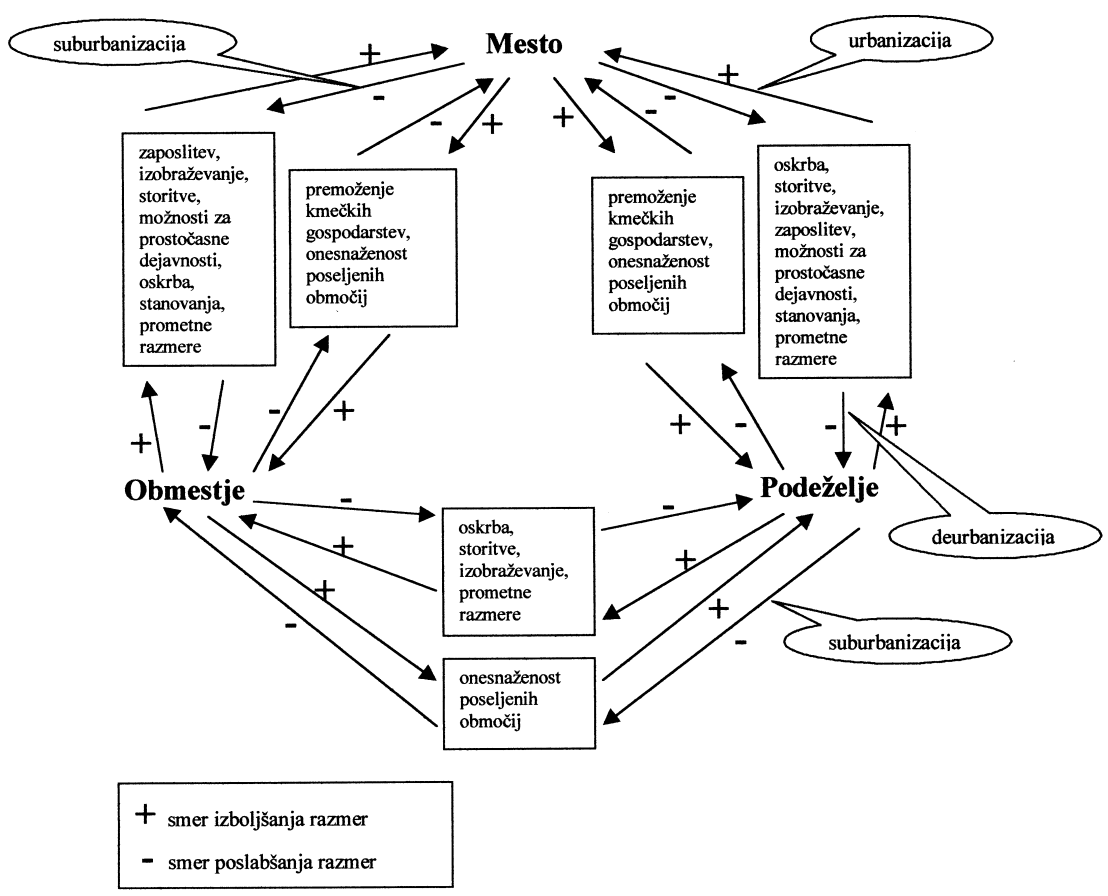

ZAKLJUČEK

Ugotovitve na splošno niso presenetljive, saj so v veliki meri skladne s stereotipnimi predstavami o razlikah med mesti in podeželjem (ter "vmesnimi" obmestji) V Sloveniji. Osrednji prispevek k poznavanju tematike je sistematična ureditev in statistična utemeljitev spoznanj o teh razlikah. V raziskavi obravnavamo celotno ozemlje Slovenije, po razmeroma majhnih enotah in s pomočjo enotne metodologije za mestna, obmestna in podeželska območja. Zato lahko, kljub sorazmerno splošni ravni spoznanj, predstavlja dobro izhodišče ali referenco za sorodne podrobnejše raziskave.

Poučen je poskus prepoznavanja mestnih, obmestnih in podeželskih območij na podlagi življenjske ravni tamkajšnjega prebivalstva. Pokažejo se slabosti uporabljene prostorske enote in opredelitve mestnih, obmestnih in podeželskih območij. Krajevne 
skupnosti ob robovih mest so praviloma heterogene, kljub temu, da so relativno majhne. To še posebej velja za manjša mesta, ki niso deljena na več krajevnih skupnosti in zajemajo še okoliška "obmestna", največkrat tudi podeželska območja. V našem poskusu to gotovo precej prispeva $\mathrm{k}$ uvrstitvi dobre desetine mestnih krajevnih skupnosti k obmestnim. Območja, ki smo jih na podlagi neposredne bližine mestom opredelili kot obmestna, se med seboj precej razlikujejo. Zlasti tista ob manjših mestih imajo lahko že močno "podeželski značaj". Če bi želeli, da nam obmestna območja predstavljajo območja suburbanizacije, bi morali za opredeljevanje uporabiti tudi druge kazalce (na primer Ravbar, 1992). V takšnem primeru bi bilo prepoznavanje obmestnih (suburbanih) in podeželskih območij na podlagi življenjske ravni tamkajšnjega prebivalstva gotovo bolj zanesljivo.

Morda najobetavnejši del prispevka je povezava medobmočnih razlik $\mathrm{v}$ življenjski ravni s prebivalstvenimi procesi, ki potekajo med območji. Model je preprost. Upamo, da je dovolj prepričljiv, da ga bodo prihodnje raziskave izpopolnile $\mathrm{z}$ uporabo podrobnejših kazalcev življenjske ravni, $\mathrm{s}$ proučitvijo relativne pomembnosti posameznih vidikov življenjske ravni za odločanje za selitev ter s proučitvijo razlik v vrednotenju teh dejavnikov med različnimi (na primer izobrazbenimi, premoženjskimi, starostnimi) skupinami prebivalcev.

\section{LITERATURA}

- de Blij H.J. 1993: Human geography: culture, society and space. Yohn Wiley \& Sons, New York.

- Drewnowski J., Scott, W. 1966: The level of living index. United Nations Research Institute for Social Development, Report No. 4, Geneve, 44-45.

- Knox P.L. 1974: Spatial variations in level of living in England and Wales in 1961. Transactions, Institute of British Geographers, 62, 1-24.

- Krampuš-Trop V. 1995: Problematika razumevanja bruto domačega proizvoda kot osnovnega kazalca gospodarske moči in življenjske ravni v Sloveniji. Organizacija, Revija za management, informatiko in kadre 3/1995. Univerza v Mariboru, Fakulteta za organizacijske vede Kranj. Založba Moderna organizacija, Kranj; 172-182.

- Krevs M. 1996: Geografski vidiki življenjske ravni prebivalstva. Spodnje Podravje s Prlekijo. Možnosti regionalnega in prostorskega razvoja. 17. zborovanje slovenskih geografov, 23.-26.10.1996, Ptuj. Zveza geografskih društev Slovenije, Ljubljana; str. 335-349.

- Krevs M. 1998: Geografski vidiki življenjske ravni prebivalstva v Sloveniji. Doktorska disertacija, Oddelek za geografijo, Filozofska fakulteta v Ljubljani.

- Malačič J. 1996: Demografija. Ekonomska fakulteta, Ljubljana.Ravbar, M. 1992: Suburbanizacija v Sloveniji. Odnosi, strukture in težnje v njenem razvoju. 
Doktorska disertacija. Oddelek za geografijo, Filozofska fakulteta, Univerza v Ljubljani.

- United Nations, 1954: International definition and measurement of standards and levels of living. United Nations, New York.

- Vrišer I. 1995: Opredelitev mest in mestnih občin v Republiki Sloveniji. Dela 11: Geografska problematika slovenskega alpskega sveta in slovenskih mest. Oddelek za geografijo, Filozofska fakulteta, Univerza v Ljubljani; 77-112.

\section{THE MAIN DIFFERENCES IN LEVEL OF LIVING BETWEEN THE SLOVENIAN URBAN, SUBURBAN AND RURAL AREAS}

\section{Summary}

Level of living is a complex and aggregate measure of circumstances (conditions) of living in a certain area, and in a certain period of time. As it has proven to be a useful tool to study differences between areas (e.g. Knox, 1974, Krevs, 1996, 1998), level of living is used to study the main differences between urban, suburban and rural areas in Slovenia.

Whole Slovenia is taken into consideration, using uniform methodology for urban, suburban and rural areas, and studied by small spatial units (local communities with the average area of 17 square kilometers; figure 1). Thirteen "partial indices of level of living" (computed on the basis of 108 indicators) are used to present diverse "contents of level of living" for every area: property and income of population, property of farms, residences, population, employment, education, supply, services, possibilities of leisure activities, personal transport accessibility, natural threats to residential areas, physical-geographical characteristics of residential areas, and pollution of residential areas. Comparisons of "profiles" of level of living and aggregate indices of level of living (figure 2), analysis of variance and discriminant analysis are the methods applied in the research.

The findings in general are not surprising, since they are similar to the stereotypes of the differences between urban, suburban and rural areas in Slovenia. The main contribution of the research to the knowledge of the differences in level of living between these areas, and to the methodology of its research, is threefold.

1. These differences are sistematically studied and the findings statisticaly tested. These are the main reasons to take this research as a starting point, or a reference for further, more detailed research in the field.

2. Urban, suburban and rural areas are best distinguished on the basis of conditions for supply, services and education, and the least distinguished by physical- 
geographical characteristics of residential areas, and property and income of population (both methods, analysis of variance and discriminant analysis, show that; table 1 and 2). Nearly $90 \%$ of urban areas were correctly identified (as urban areas) on the basis of partial indices of level of living, but only about $70 \%$ of suburban (as suburban) and rural (as rural) areas. The latter is particularly due to heterogenous local communities on the edges of smaller towns, and to oversimplified definition of suburban areas (based only on the distance from continuously populated urban areas). More appropriate definition of the latter should lead to better identification of suburban and rural areas on the basis of level of living indices.

3. The aim of migrations can be defined as improvement of the level of living of migrants (and their families). The differences between urban, suburban and rural areas can easily be transformed into a model of possible objective factors of migrations among these areas in Slovenia (figure 3). It can be used to describe the effects of migrations from one "type" of area to another, and to speculate about possible factors that influence the actual decisions to migrate.

Figure 3: Model of possible objective factors of migrations between urban, suburban and rural areas in Slovenia. The contents of level of living that change the most with a migration in certain direction, are listed by descending reliability of the change.

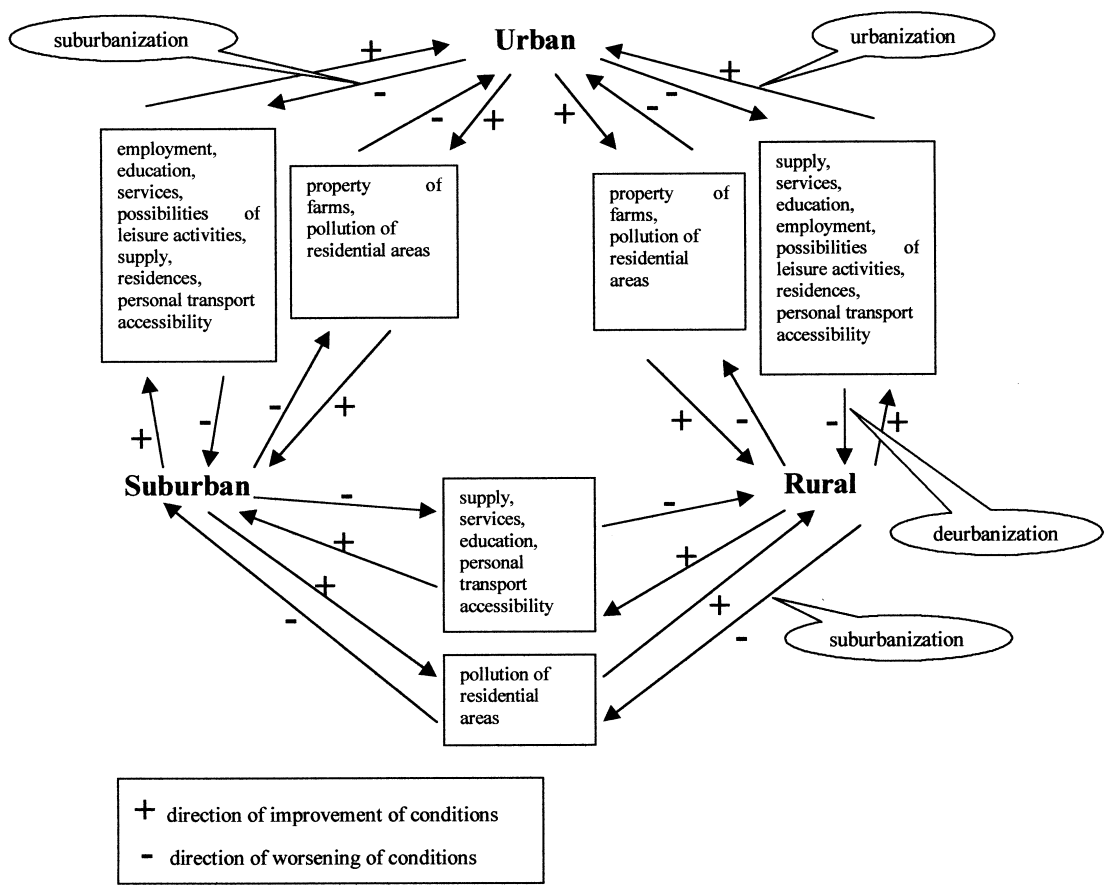

